\title{
Localisation of the gene for Emery-Dreifuss muscular dystrophy to the distal long arm of the $\mathrm{X}$ chromosome
}

\author{
N S T THOMAS*, H WILliAMS*, L J ELSAS $\dagger$, L C HOPKINS $\dagger$, \\ M SARFARAZI*, AND P S HARPER* \\ From *the Section of Medical Genetics, University of Wales College of Medicine, Heath Park, Cardiff CF4 \\ $4 X N$; and the Departments of Neurology and Pediatrics, Emory University School of Medicine, 1400 \\ Clifton Road, NE Atlanta, Georgia 30332, USA.
}

SUMMARY The linkage relationships of the gene for Emery-Dreifuss muscular dystrophy have been analysed in a large American kindred using DNA probes from different regions of the $X$ chromosome. Close linkage was found with the locus for factor VIII, with no recombinants in 12 opportunities (maximum lod score 4.3), and with locus DXS15 (two recombinants in 17 opportunities, maximum lod score 2.9 at $\theta=10 \mathrm{cM}$ ). No linkage was found with probes pERT87 and 754, which are closely linked to Duchenne and Becker muscular dystrophies at Xp21. These results confirm a separate localisation on the distal part of the long arm at q27-28 for Emery-Dreifuss muscular dystrophy and should provide the basis for prenatal diagnosis and improved carrier detection in this disorder if the linkage is confirmed to be close.

Emery-Dreifuss muscular dystrophy is a rare but clinically distinctive $\mathrm{X}$ linked muscular dystrophy. The principal features separating this disorder from the commoner and more widely recognised Becker and Duchenne muscular dystrophies include prominent and early cardiac involvement, widespread joint contractures, relatively mild and slowly progressive muscle disease, and a distribution of muscle involvement that may selectively involve the peroneal muscles in addition to the proximal groups.

The disorder was originally described by Dreifuss and Hogan ${ }^{1}$ and by Emery and Dreifuss ${ }^{2}$ in America, but has subsequently been recognised in other parts of the world.

Until recently there was no clear information on whether the various $\mathrm{X}$ linked muscular dystrophies were determined by one or by separate genetic loci. Initial evidence suggested genetic linkage between Becker muscular dystrophy and colour blindness, ${ }^{3}$ but linkage analysis with $\mathrm{X}$ chromosome DNA polymorphisms has since shown conclusively that both Becker and Duchenne dystrophies are localised on the short arm at band p21. ${ }^{45}$ The two forms may well be allelic, though this has yet to be proven.

The first clear suggestion of a separate localisation for Emery-Dreifuss dystrophy came from the finding of Boswinkel et at that there was frequent

Received for publication 30 June 1986.

Accepted for publication 4 August 1986. recombination with short arm $\mathrm{X}$ chromosome DN markers closely linked to $D M D$, and that the distab. long arm probe DX13 (DXS15) showed evidence supporting linkage. An earlier report by Thomas et $\mathrm{al}^{\mathrm{t}}$ of close linkage between colour blindness and an $\mathrm{X}$ linked scapuloperoneal myopathy, with no recombinants in 10 meioses, may have been studying the same condition. We present data from a large American kindred with Emery-Dreifuss dystrophy, originally described by Hopkins et al, ${ }^{8}$ which confirms a distal long arm localisation for this locus. The use of a single large kindred avoids the problems of combining data from families which may be heterogeneous.

\section{Methods}

The kindred under study lives in the North Georgia region of the south-east United States and clinical features have been fully reported previously. ${ }^{8}$ Cardiac conduction defects are a prominent and early feature of affected males, muscle weakness is relatively mild and of a humeroperoneal distribution, while early joint contractures occur at the neck and elbows. All males sampled were carefully assessed clinically. Colour blindness was tested for using Isihara plates.

DNA was isolated from venous blood by the method of Kunkel et al and restriction digests, agarose electrophoresis, and Southern blotting were 
TABLE 1 DNA probes studied.

\begin{tabular}{|c|c|c|c|c|c|c|}
\hline \multirow[t]{2}{*}{ Probe } & \multirow{2}{*}{$\begin{array}{l}\text { HGM } \\
\text { nomenclature }\end{array}$} & \multirow[t]{2}{*}{ Localisation } & \multirow[t]{2}{*}{ Source } & \multirow[t]{2}{*}{$R F L P$} & \multicolumn{2}{|l|}{ Alleles } \\
\hline & & & & & Sizes $(k b)$ & Frequency \\
\hline DX13 & $D X S 15$ & $\mathrm{Xq} 28$ & $\begin{array}{l}\text { K E Davies } \\
\text { (Oxford) }\end{array}$ & $B g I I I$ & $\begin{array}{l}5 \cdot 4 \\
2 \cdot 0\end{array}$ & $\begin{array}{l}0.38 \\
0.62\end{array}$ \\
\hline $\begin{array}{r}\text { Factor } \\
\text { VIII }\end{array}$ & $F 8 C$ & $\mathrm{Xq} 28$ & $\begin{array}{l}\text { J Gitschier } \\
\text { (San Francisco) }\end{array}$ & $B c l I$ & $\begin{array}{l}1 \cdot 17 \\
0 \cdot 90\end{array}$ & $\begin{array}{l}0.29 \\
0.71\end{array}$ \\
\hline $\begin{array}{l}\text { Factor } \\
\text { IX }\end{array}$ & $F 9$ & $\mathrm{Xq} 26-27 \cdot 3$ & $\begin{array}{l}\text { G G Brownlee } \\
\text { (Oxford) }\end{array}$ & TaqI & $\begin{array}{l}1 \cdot 8 \\
1 \cdot 3\end{array}$ & $\begin{array}{l}0.71 \\
0.29\end{array}$ \\
\hline 754 & $D X S 84$ & $\mathrm{Xp} 21$ & $\begin{array}{l}\text { P Pearson } \\
\text { (Leiden) }\end{array}$ & Pst $\mathrm{I}$ & $\begin{array}{r}12 \cdot 0 \\
9 \cdot 0\end{array}$ & $\begin{array}{l}0.62 \\
0.38\end{array}$ \\
\hline pERT87-1 & $D X S 164$ & Xp21 & $\begin{array}{l}\text { L M Kunkel } \\
\text { (Boston) }\end{array}$ & $X m n \mathbf{I}$ & $\begin{array}{l}8 \cdot 7 \\
7 \cdot 5\end{array}$ & $\begin{array}{l}0.66 \\
0.34\end{array}$ \\
\hline
\end{tabular}

carried out as previously reported.' The DNA probes studied are shown in table 1 and cover two major regions of the $\mathrm{X}$ chromosome: the $\mathrm{p} 21$ region known to involve Duchenne and Becker dystrophies and the distal part of the long arm.

Lod scores were calculated using the programme LIPED. ${ }^{10}$

TABLE 2 Linkage analysis between Emery-Dreifuss muscular dystrophy and the marker loci.

\begin{tabular}{|c|c|c|c|c|c|}
\hline$\theta$ & $F 8 C$ & DXS15 & $F 9$ & $D X S 84$ & DXS164 \\
\hline 0.00 & $4 \cdot 249$ & $-\infty$ & $-\infty$ & $-\infty$ & $-\infty$ \\
\hline 0.01 & $4 \cdot 185$ & 1.607 & $-8 \cdot 104$ & -2.921 & -9.427 \\
\hline 0.05 & 3.922 & $2 \cdot 686$ & $-4 \cdot 070$ & -1.006 & $-4 \cdot 703$ \\
\hline $0 \cdot 10$ & $3 \cdot 578$ & $2 \cdot 871$ & -2.462 & -0.336 & $-2 \cdot 814$ \\
\hline $0 \cdot 15$ & $3 \cdot 215$ & $\frac{.011}{2 \cdot 783}$ & -1.605 & -0.045 & $-1 \cdot 808$ \\
\hline $0 \cdot 20$ & $2 \cdot 831$ & $2 \cdot 566$ & $-1 \cdot 058$ & 0.089 & $-1 \cdot 168$ \\
\hline 0.25 & $2 \cdot 422$ & $2 \cdot 263$ & -0.682 & $0 \cdot 141$ & -0.734 \\
\hline $0 \cdot 30$ & 1.986 & 1.893 & -0.415 & $0 \cdot 144$ & -0.434 \\
\hline 0.35 & $1 \cdot 519$ & 1.460 & -0.226 & $0 \cdot 119$ & -0.229 \\
\hline 0.40 & $1 \cdot 016$ & 0.967 & -0.099 & 0.081 & -0.097 \\
\hline 0.45 & 0.483 & 0.433 & -0.024 & 0.040 & -0.023 \\
\hline
\end{tabular}

\section{Results}

Table 2 shows the estimated lod scores between Emery-Dreifuss muscular dystrophy and the various marker loci at different values of recombination fraction $(\theta)$. Table 3 gives the numbers of recombinants for specific meioses and the figure shows the pedigree structure and the genotype for the loci $D X S 15$ and $F 8 C$.

TABLE 3 Recombinants between Emery-Dreifuss muscular dystrophy and the marker loci.

\begin{tabular}{|c|c|c|c|c|}
\hline \multirow[t]{3}{*}{ Locus } & \multicolumn{2}{|l|}{ Phase known } & \multirow{2}{*}{$\begin{array}{l}\text { Phase } \\
\text { unknown }\end{array}$} & \multirow{3}{*}{$\frac{\text { Total }}{R / R+N R}$} \\
\hline & \multirow[t]{2}{*}{ Recombinants } & \multirow{2}{*}{$\begin{array}{l}\text { Non- } \\
\text { recombinants }\end{array}$} & & \\
\hline & & & $R: N R$ & \\
\hline$F 8 C$ & 0 & 2 & $0: 10$ & $0 / 12$ \\
\hline DXS15 & 2 & 5 & $0: 10$ & $2 / 17$ \\
\hline F9 & 0 & 5 & $6: 3$ & $6 / 14$ \\
\hline$D X S 84$ & 1 & 2 & $5: 6$ & $6 / 14$ \\
\hline DXS164 & 3 & 4 & $6: 6$ & $9 / 21$ \\
\hline
\end{tabular}

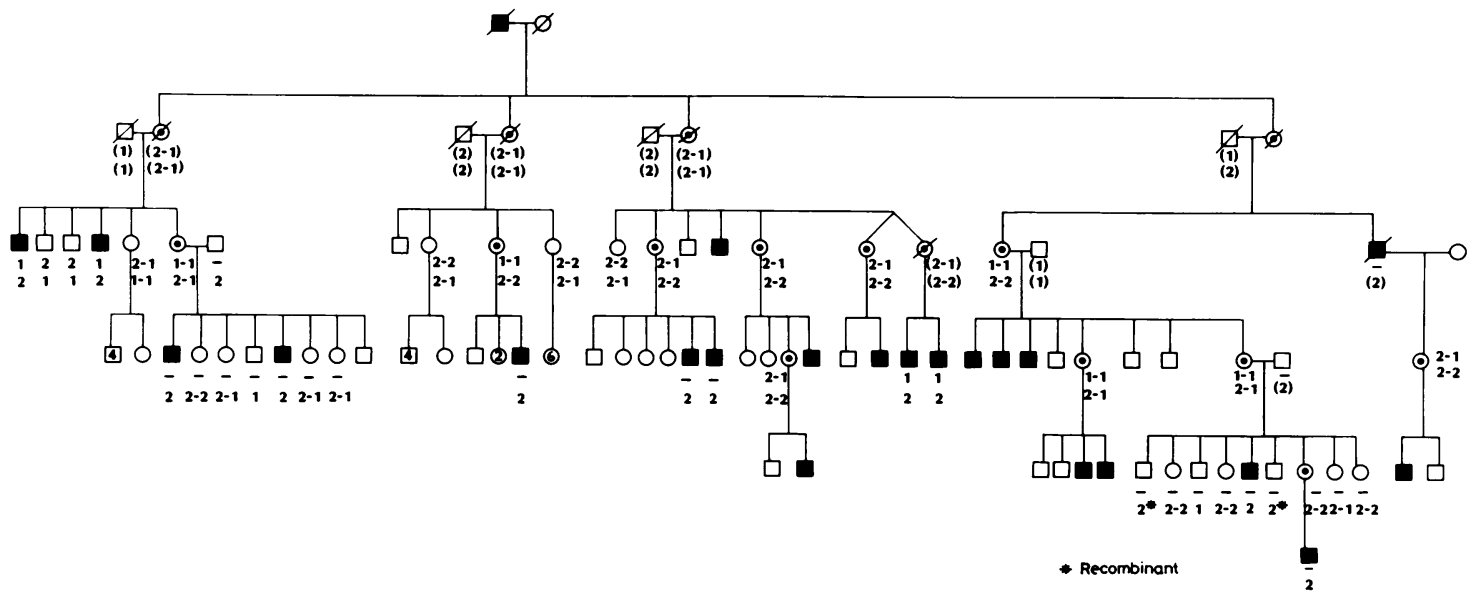

FIGURE Pedigree of kindred with Emery-Dreifuss muscular dystrophy showing genotypes for F8C (upper) and DXS15 (lower). Some parts of the kindred not available for testing have been omitted. 
It can be seen that the lod scores for the two short arm probes 754 and pERT87-1, which are closely linked to Duchenne and Becker muscular dystrophies, are negative. The values for the two loci located at Xq27-28, F8C and DXS15, show clear linkage, with no recombinants so far detected for $F 8 C$ and only two recombinants out of 20 for DXS15. The data for $F 9$, situated proximally to the fragile site at $\mathrm{Xq} 27 \cdot 3$, show no measurable linkage, with five recombinants out of 15 scorable meioses.

The kindred was not informative for colour blindness.

\section{Discussion}

The results from this kindred leave no doubt that the locus for Emery-Dreifuss muscular dystrophy is distally located on the long arm of the $\mathrm{X}$ chromosome and they exclude a short arm localisation comparable to that of the Duchenne and Becker forms. The localisation at $\mathrm{q} 27-28$ is similar to that suggested by Boswinkel et $a t^{6}$ and to that found previously by Thomas $\mathrm{et}^{7}$ with colour blindness if, as seems likely, their kindred had Emery-Dreifuss muscular dystrophy.

Although we have found closer linkage with $F 8 C$ than with $D X S 15$, we have no definite information on the relative ordering of the three loci yet, since the portion of the kindred showing recombination with DXS15 was uninformative for F8C. Further studies on other branches of this kindred are in progress, and several other probes located terminally on $\mathrm{Xq}$, including St14, are being analysed, which should throw light on the precise ordering of the disorder in relation to the various marker loci.* To our knowledge no case of haemophilia $A$ and a myopathy suggestive of Emery-Dreifuss dystrophy has been recorded in the same patient, as might be expected to occur occasionally due to a deletion if the two loci are indeed very close.

Although Emery-Dreifuss muscular dystrophy is not such a disabling disorder physically as the Duchenne and Becker forms, the combination of progressive muscle weakness and, in particular, the serious cardiac complications result in considerable morbidity and at times mortality, so that accurate identification of carrier status and prenatal prediction using closely linked probes should be of help to family members. This kindred has previously been the subject of a cost-benefit analysis of preventive measures that has documented their economic

*We have recently completed linkage analysis using probe St14-1 (DXS52) and have found two recombinants in 38 informative meioses; these are the same two recombinants identified by DX13 (DXS15). The linkage results for Emery-Dreifus $/ \mathrm{St} 14-1$ give a maximum lod score of 6.95 at $6 \mathrm{cM}$. value. ${ }^{11}$ Further information on the precise localisation and exclusion of further genetic heterogeneity will be needed before this approach can be used confidently in prediction and it will be important for all large families with the disorder to be studied on a world wide basis in view of its rarity.

The identification of a clearly separate genetic locus for Emery-Dreifuss muscular dystrophy indicates a basic defect distinct from that responsible for Duchenne and Becker dystrophies. It also emphasises the need for careful clinical distinction of the Becker and Emery-Dreifuss dystrophies if misinterpretation of genetic linkage data in prediction is to be avoided.

We thank Dr Jane Gitschier for the gift of the factor 8 probe and Dr Kay Davies for probe DX13. Other probes were kindly donated by $\mathrm{Dr} \mathrm{L}$ Kunkel (pERT87), Professor P Pearson (754), Dr J-L Mandel (St14), and Professor G Brownlee (factor 9). This work was supported by the Muscular Dystrophy Association of America and the Muscular Dystrophy Group of Great Britain.

\section{References}

1 Dreifuss FE, Hogan GR. Survival in X-chromosomal muscular dystrophy. Neurology (Minneap) 1961;11:734-7.

2 Emery AEH, Dreifuss FE. Unusual type of benign X-linked muscular dystrophy. $J$ Neurol Neurosurg Psychiatry 1966;29:338-42.

3 Skinner R, Smith C, Emery AEH. Linkage between the loci for benign (Becker-type) X-borne muscular dystrophy and deutan colour blindness. J Med Genet 1974;11:317-20.

4 Kingston HM, Thomas NST, Pearson PL, Sarfarazi M, Harper PS. Genetic linkage between Becker muscular dystrophy and a polymorphic DNA sequence on the short arm of the $X$ chromosome. J Med Genet 1983;20:255-8.

5 Brown CS, Thomas NST, Sarfarazi M, et al. Genetic linkage relationships of seven DNA probes with Duchenne and Becker muscular dystrophy. Hum Genet 1985;71:62-74.

6 Boswinkel E, Walker A, Hodgson S, et al. Linkage analysis using eight DNA polymorphisms along the length of the $\mathrm{X}$ chromosome locates the gene for Emery-Dreifuss muscular dystrophy to distal Xq. Cytogenet Cell Genet 1985;40:586.

7 Thomas PK, Calne DB, Elliot CF. X-linked scapuloperoneal syndrome. J Neurol Neurosurg Psychiatry 1972;35:209-15.

8 Hopkins LC, Jackson JA, Elsas LJ. Emery-Dreifuss humeroperoneal muscular dystrophy: an X-linked myopathy with unusual contractures and bradycardia. Ann Neurol 1981;10:230-7.

9 Kunkel LM, Smith KD, Boyer SH, et al. Analysis of human Ychromosome-specific reiterated DNA in chromosome variants. Proc Natl Acad Sci USA 1977;74:1245-9.

10 Ott $\mathrm{J}$. Estimation of the recombination fraction in human linkage studies. Am J Hum Genet 1974;26:588-97.

11 Wright ML, Elsas LJ. Application of benefit-to-cost analysis to an X-linked recessive cardiac and humeroperoneal neuromuscular disease. Am J Med Genet 1980;6:315-29.

Correspondence and requests for reprints to Professor P S Harper, Section of Medical Genetics, University of Wales College of Medicine, Heath Park, Cardiff CF4 4XN. 